\title{
INTRA- AND INTERSPECIFIC RECOMBINATION IN THE NATURAL CONDITION OF PEPPER VEIN YELLOWS VIRUS AND RESPONSE OF PVR ALLELES IN PEPPER
}

\author{
ARPACI, B. B. \\ Department of Horticulture, Faculty of Agriculture, University of Kilis 7 Aralik, 79100 Kilis, Turkey \\ (e-mail: bbarpaci@kilis.edu.tr; phone: +90-348-814-2666; fax: +90-348-814-2667) \\ (Received $9^{\text {th }}$ Jun 2019; accepted $10^{\text {th }}$ Sep 2019)
}

\begin{abstract}
Since their first observing in Japan, poleroviruses have threatened pepper cultivation all around the World. Symptoms of vein yellowing originating from poleroviruses have become widespread in both open field and protected pepper cultivation areas recently. In this work samples collected from highly infected pepper fields in South East Turkey have been determined as Pepper Vein Yellows Virus (PVYV) and Beet Western Yellows Virus (BWYV) (genus Polerovirus, family Luteoviridae). Recombinant PVYV isolates have been observed from intra and interspecific combination in relation to part of the RNA-dependent RNA polymerase coding region subjected to recombination detection methods. One of the PVYV isolates has induced recombination between BWYV and PVYV and located middle of the PVYV and BWYV isolates. Another isolate recombined from intraspecific combination has been transferred onto pepper genotypes carrying pvr alleles and landraces under both artificial and natural conditions to determine their response. None of the pvr alleles in pepper genotypes used in this study could contribute to resistance to PVYV isolates.
\end{abstract}

Keywords: poleroviruses, capsicum, resistance, Luteoviridae, genetic diversity

\section{Introduction}

Pepper crops are exposed to many pests and diseases because of their wide geographical distribution and cultivation areas. Mono-cultivation of pepper intensively along with climate changes increase the vector and virus infection in Mediterranean Basin. Capsicum spp. is exposed to over 70 viruses and pepper production is limited by more than 20 important plant viruses (Florini and Zitter, 1986; Green and Kim, 1991; Moury and Verdin, 2012). The new viruse causing interveinal yellowing symptoms was recently sequenced and identified by Murakami et al. (2011) as Pepper vein yellowing virus (PeVYV). Denomination and identification starts in Japan with Pepper vein yellows virus (PeVYV) (Yonaha et al., 1995) and continue Pepper yellow leaf curl virus (PYLCV) in Israel (Dombrovsky et al., 2010), Pepper vein yellowing virus (PeVYV) in Japan (Murakami et al., 2011), Pepper vein yellows virus (PVYV) in Turkey and Tunisia (Buzkan et al., 2013) and Pepper Yellows Disease (PYD) in Greece (Lotos et al., 2017). Regardless of nomenclature many researcher reported causing yellowing symptoms in pepper having similar genome organization in Spain (Villanueva et al., 2013), India, Indonesia, Mali, Philippines, Thailand and Taiwan (Knierim et al., 2013), Sudan (Alfaro-Fernández et al., 2014), China (Tan et al., 2015), Australia (Maina et al., 2016) and Saudi Arabia (Kamran et al., 2017).

Poleroviruses belonging Luteoviridae have icosahedral virions in $26-30 \mathrm{~nm}$ diameter including about $6.2 \mathrm{~kb}$ positive-sense single-stranded RNA without envelope (Kenyon et al., 2014). Luteoviridae family tends to recombination related their nucleotide substitution of coat protein region (Pagán and Holmes, 2010). Recombination and mutation are main factor to generate genetic variability for the 
viruses (Desbiez et al., 2011). Buzkan et al. (2013) emphasized the recombinant nature of PVYV compared different countries related their RNA-dependent RNA polymerase region. Fiallo-Olivé et al. (2018) confirmed recombinant structure of PVYV by phylogenetic analysis of full length genome and classified the virus from PeVYV-1 to PeVYV-5 related their genome organization.

Breeding sweet and large-fruited blocky-type peppers has been limited because of undesirable traits exist among wild accessions. Wild accessions of Capsicum annuum species differ in many yield and quality characters comprising cultivated varieties (Ben-Chaim and Paran, 2000). Disease resistance genes from wild accessions have been transferred by many researchers into sweet blocky types (Lefebvre et al., 1995; Daubeze et al., 1995; Caranta et al., 1997; Lapidot et al., 1997; Paran et al., 1998).

In this study the recombination events of PVYV isolates were determined from one location highly infected by poleroviruses. Both PVYV and BWYV (Beet western yellows virus) were determined in the same location and recombination evidence was calculated intra- and interspecific combination. Response of local pepper landraces, varieties and genotypes possessing $p v r$ alleles to PVYV were also determined.

\section{Materials and methods}

\section{Plant material}

Pepper genotypes including different genotypes and varieties were used to test resistance against PVYV in natural and artificial aphid transmission conditions. PVYV isolate 24 were inoculated by aphid (Myzus persicae) transmission on the pepper plants carrying pvr2 alleles in Yolo Wonder (YW), Yolo Y (YY), Florida VR2 (VR2) and W4. YY, VR2 and W4 are homozygous for the $p v r 2^{+}, p v r 2^{1}, p v r 2^{2}$, and Pvr4 resistance genes, respectively. Criollo de Morelos 334 was also used as control plants in the experiment. Şahinbey variety and eleven inbred line having blocky pod type were used for resistance experiment.

\section{Virus detection}

The presence of PVYV in leaf samples was determined both reverse transcription polymerase chain reaction (RT-PCR) and Double antibody sandwich enzyme-linked immunosorbent assay (DAS-ELISA) with cucurbit aphid-borne yellows virus (CABYV) antibodies which are strongly cross reacted poleroviruses (Buzkan et al., 2013). Total RNAs were extracted from symptomatic pepper leaf samples and aphids fed on leaves using TRI Reagent (Sigma) according to the instructions. RT-PCR method was carried out with Moloney murine leukemia virus (M-MuLV) reverse transcriptase and Taq DNA polymerase (Invitrogen).

Two-step reverse transcription polymerase chain reactions (RT-PCRs) were performed by using primers Pol-G-F (5'-GAYTGCTCYGGYTTYGACTGGAG-3') and Pol-G-R (5'-GATYTTATAYTCATGGTAGGCCTTGAG-3') designed by Knierim et al. (2010) from conserved regions from all poleroviruses. PCR conditions were at $60{ }^{\circ} \mathrm{C}$ for annealing temperature and $90 \mathrm{~min}$ for extension time. RT-PCR amplification products at $1.1-\mathrm{kb}$ (RNA-dependent RNA polymerase coding region, the intergenic noncoding region and part of the coat protein coding region) were directly sequenced with primer Pol-G-F by MEDSANTEK (Istanbul, Turkey). 


\section{Recombination analysis}

Aligned sequences by ClustalW program were implemented in the software MEGA 7 (Kumar et al., 2016) and confirmed Blastn program. Neighbor-joining, Tamura-Nei model was implemented with 500 bootstrap resampling to assess the robustness of branches (Saitou and Nei, 1987). Recombination events between sequences were predicted using RDP4 software and confirmed by boot scan analysis using SimPlot software (http://sray.med.som.jhmi.edu/SCRoftware) with the Kimura 2-parameter distance model (Lole et al., 1999).

\section{PVYV isolates and inoculation}

Thirty pepper plants showing inter-veinal yellowing and curling symptoms on leaves were collected diagonally in one highly infected field with poleroviruses (Bogazkirim, Dorucak/Musabeyli/Kilis/Turkey $36^{\circ} 49^{\prime} 49.9^{\prime \prime} \mathrm{N}$ and $36^{\circ} 51^{\prime} 47.2^{\prime \prime} \mathrm{E}$ ) in Kilis province (southeastern Turkey) in August 2015 (Fig. la, b and c). The plants were numbered, potted and transferred from field to insect proof greenhouse. The PVYV isolates were detected as described at virus detection section by reverse transcription polymerase chain reaction (RT-PCR) and Double antibody sandwich enzyme-linked immunosorbent assay (DAS-ELISA) and isolate 24 determined as recombinant isolate was used as viral material.

\section{Artificial inoculation}

Aphids (Myzus persicae) collected from upper leaves of peach trees were propagated on sweet pepper (cv. Yolo Wonder) plants at the true leaf stage to use aphid transmission. Isolate 24 was used to determine response of pepper genotypes to PVYV. Aphids propagated on Yolo Wonder leaves were allowed a 48-h acquisition access feeding period on plant infected by isolate 24. Two aphids were transferred from infected plants to lower leaf surface of healthy ten pepper plants of each genotype at four-leaf stage for artificial inoculation. Plants were treated with the insecticide after inoculation access feeding of $48 \mathrm{~h}$. PVYV could be transmitted efficiently by at least two aphid vectors $M$. persicae (Dombrovsky et al., 2010).

\section{Transmission on greenhouse conditions}

Artificially infected ten Yolo Wonder plants by isolate 24 were transplanted in greenhouse along with the genotypes which will have been tested. Fifteen plants of each genotype were transplanted at four true leaves stage between 70 and $50 \mathrm{~cm}$ spaces in rows. Twenty aphids were placed on each infected Yolo Wonder plants. Three months after planting PVYV were detected on genotypes both DAS-ELISA and RT-PCR. Isolate 24 was re-isolated from plants (Fig. 1e) and confirmed by sequencing (Fig. 2a).

\section{Results and discussion}

Because of the lack of specific antibodies to PVYV and presence of serological cross-reactions between these viruses, CABYV antibodies were used in DAS-ELISA (Buzkan et al., 2013). Twenty-nine of the collected plants strongly reacted to CABYV antibodies. Pol-G-F and Pol-G-R primers designed by Knierim et al. (2010) from conserved regions in the polerovirus genome were used and 1.1-kbp amplicons were 
produced after two-step reverse transcription polymerase chain reactions. Fifteen of the twenty-nine samples reacted CABYV antibodies were shown similarity with PVYV and seven of the samples were identified as BWYV after using the Blastn program after aligned using the ClustalW software. Six of the RT-PCR products directly sequenced by Pol-G-F primer could not been identified because of low sequencing quality (Table 1). Aphids fed on pepper plants infected isolate 24 was also confirmed by RT-PCR and sequence analysis.

Table 1. Total number of samples and number of isolates determined belonging polerovirus genus

\begin{tabular}{c|c|c|c|c}
\hline $\begin{array}{c}\text { Number of samples } \\
\text { cross-reacted } \\
\text { CABYV antisera }\end{array}$ & $\begin{array}{c}\text { Number of samples } \\
\text { determined as } \\
\text { PVYV }\end{array}$ & $\begin{array}{c}\text { Number of samples } \\
\text { determined as } \\
\text { BWYV }\end{array}$ & $\begin{array}{c}\text { Number of samples } \\
\text { not detected any } \\
\text { Polerovirus }\end{array}$ & $\begin{array}{c}\text { Total number } \\
\text { of samples }\end{array}$ \\
\hline 29 & 15 & 7 & 8 & 30 \\
\hline
\end{tabular}

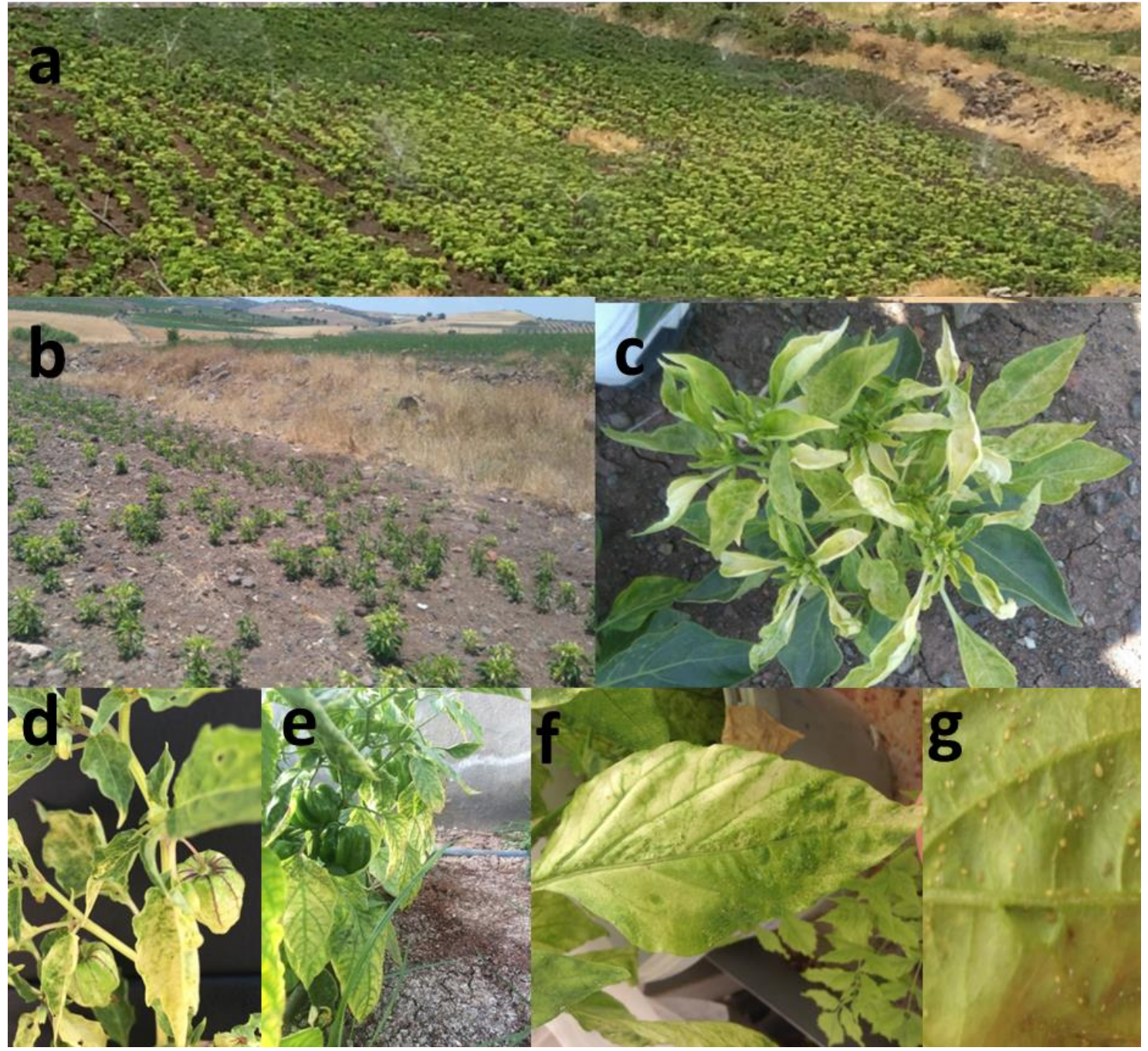

Figure 1. Highly infected pepper plants by poleroviruses in open field condition in Kilis $(a, b, c)$

Physalis spp. infected by PVYV at the border of the pepper cultivation area (d) Blocky type landrace of Kilis infected by recombinant PVYV isolate 24 in greenhouse (e) Aphid transmitted $P V Y V$ isolate 24 on Yolo Wonder pepper plant $(f, g)$ 
Intergenic noncoding region and part of ORF3 (open read frame 3: the coat protein coding region) of sequences were trimmed and aligned by ClustalW (Thompson et al., 2003) and converted the file format to detect recombination events. Part of the RNAdependent RNA polymerase coding region subjected to recombination detection methods by RDP4 software (Martin et al., 2015). Two of seven different methods implemented in the software RDP4 showed small recombination evidence $\left(\mathrm{P}=10^{-2}\right.$ to $10^{-5}$ ) in isolate 24 (Fig. 2). This recombination event would involve isolate 15 as a major parent while isolate 21 used to infer unknown parents (Fig. 3). Recombination event confirmed by SimPlot software (Lole et al., 1999) with the Kimura 2-parameter with 100 replicates (Fig. 4).
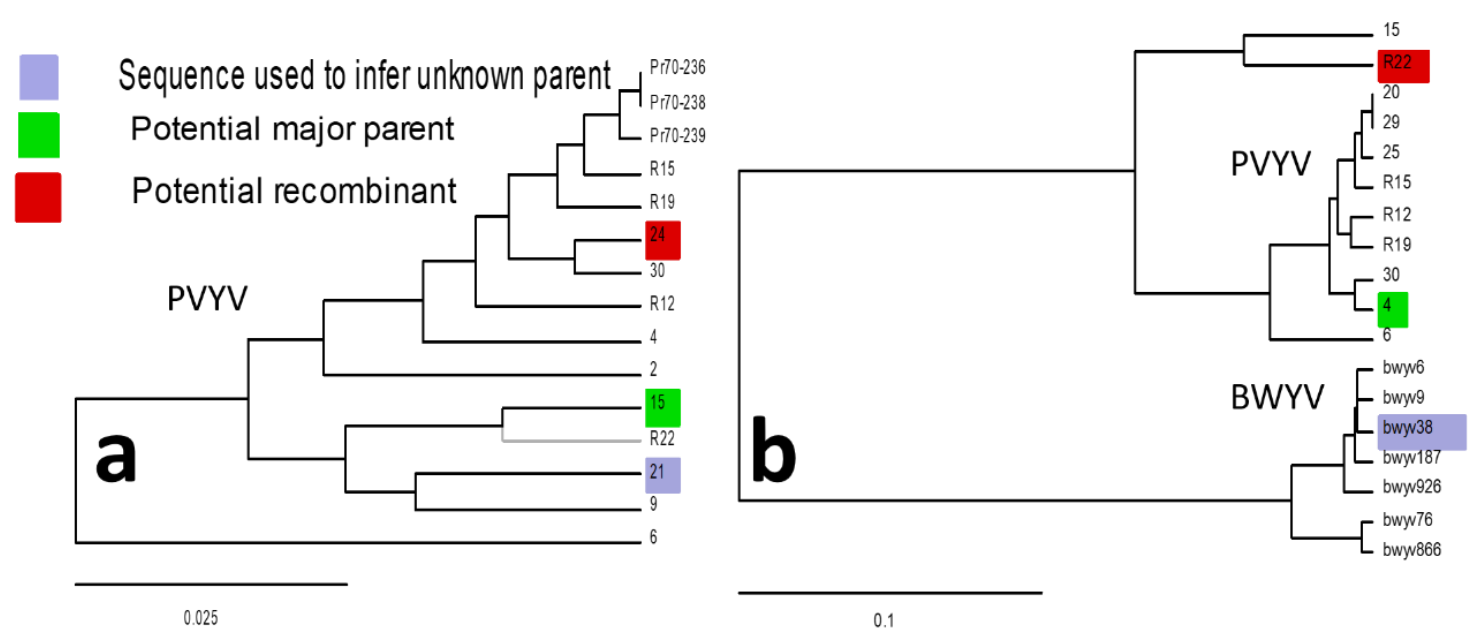

Figure 2. Tree topology test for recombinant and parental isolates for PVYV isolates (a) and tree topology test for recombinant and parental isolates for both PVYV and BWYV $(b)$

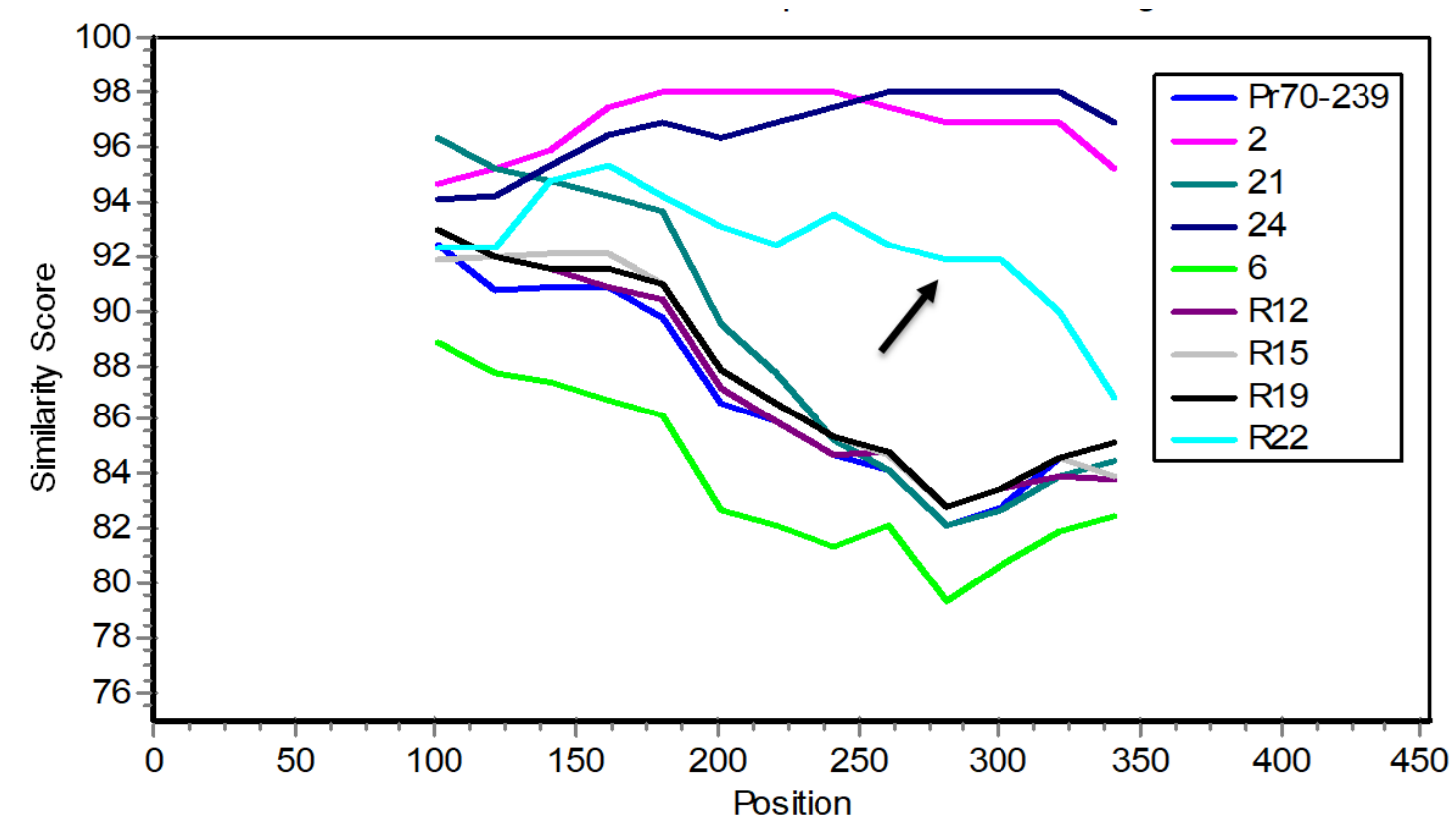

Figure 3. Similarity plot diagram comparing the nucleotide sequence of PVYV isolate from one pepper cultivation field. Recombinant isolate R22 was indicated with arrow 


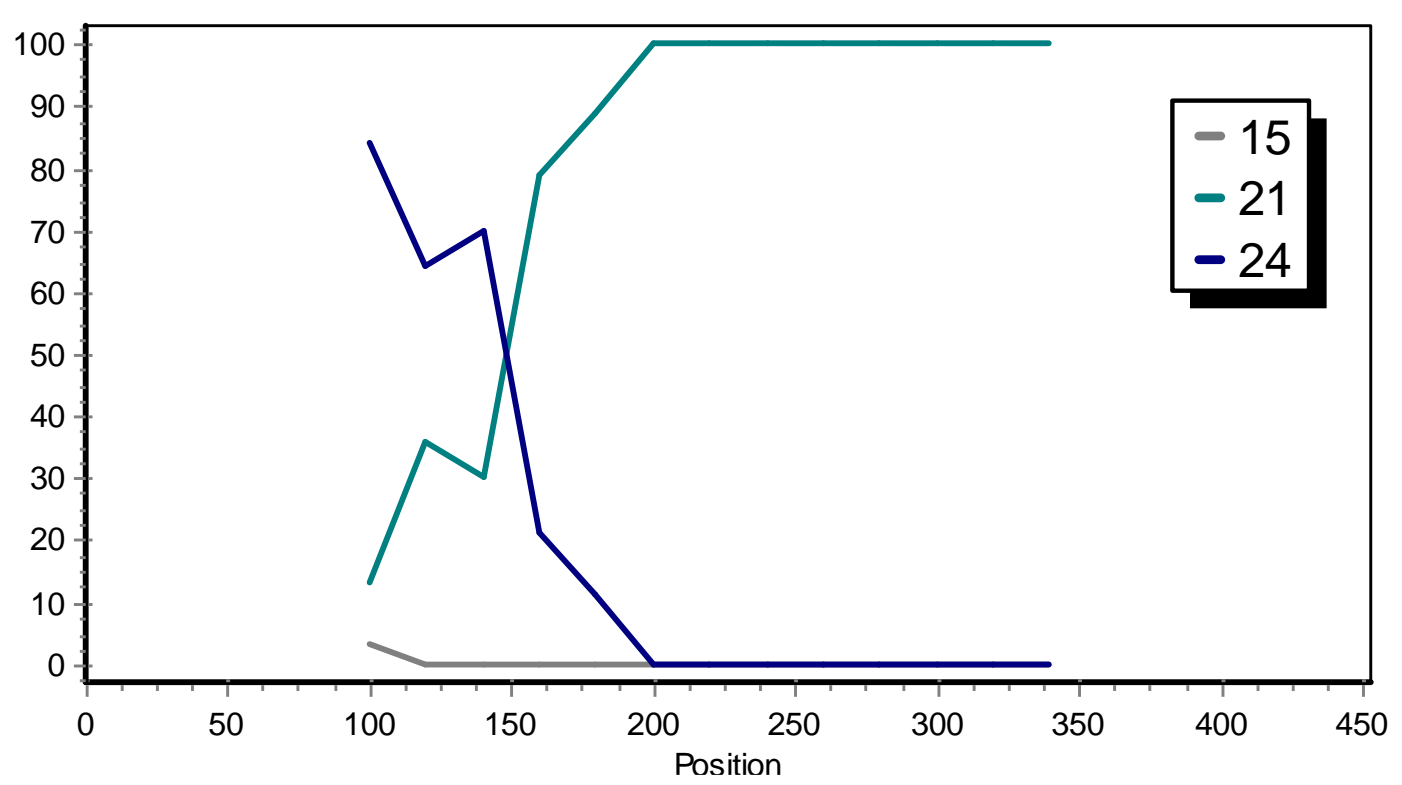

Figure 4. Recombination position of the nucleotide sequence of parental isolates

Recombination event was also detected between BWYV and PVYV. Recombination evidence was confirmed by GENECONV (1.292 x 10-2) using RDP4 software (Fig. 5).

Isolate R22 was recombined by PVYV isolate 4 and BWYV isolate 38. Putative recombinant isolate 24 rooted different groups from their estimated parents isolate 15 and 21. PVYV isolates have shown between 79 and 98\% similarity (Figs. 2 and 3) Neighbor-Joining phylogeny implemented in MEGA 7 using Tamura-Nei distance with 500 bootstrap re-samplings grouped BWYV and PVYV in different clades. Recombinant PVYV isolate R22 was placed between BWYV and PVYV in relation to part of the RNA-dependent RNA polymerase coding region (Fig. 6). Fiallo-Olivé et al. (2018) declared that PeVYV was a recombinant of CABYV and TVDV concerning with whole genome sequencing.

Buzkan et al. (2013) found a high prevalence of poleroviruses in open field pepper cultivation areas both Turkey and Tunisia. They showed an evidence PVYV-like isolate recombined from another region of Tunisia. Dombrovsky et al. (2010) hypothesized that PeVYV was a recombinant of Tobacco vein distorting virus (TVDV) while Fiallo-Olivé et al. (2018) were declared it as distinct from other poleroviruses. They proposed the name of the virus as Pepper vein yellows virus and classified from 1 to 5 corresponding to their complex genome organization due to recombination events. In this study, recombinant isolates corresponding C-terminal part of the RNA-dependent RNA polymerase were determined only one location pepper cultivation area widespread infected by poleroviruses (Fig. 1). Pagán and Holmes (2010) determined the occurrence of recombination within and between the $\mathrm{RdRp}$ and $\mathrm{CP}$ genes for each of the Luteoviridae species.

Pleiotropic effects of both viral and coat protein genome mutations have been observed on Capsicum. Pepper resistance genes and alleles whether dominant or recessive are efficient against several potyviruses. Sacchi et al. (2003) identified potyviruses in Brazil and improved resistant progenies to Potato Virus Y. Dominant Pvr4 gene provides resistance to PepSMV (Pepper severe mosaic virus) and PTV (Peru tomato mosaic virus), but carrying genotypes this gene are susceptible to ChiVMV 
(Chilli veinal mottle virus), PVMV (Pepper veinal mottle virus) and TEV (Tobacco etch virus) (Janzac et al., 2009). Recessive genes pvrl and pvr2 in pepper have been observed for resistance to potyviruses including TEV but many virulent strains overcome most of these recessive genes (Parrella et al., 2002). Yolo Wonder $\left(p v r 2^{+}\right)$, Yolo Y $\left(p v r 2^{l}\right)$, Florida VR2 $\left(p v r 2^{2}\right)$ and W4 (Pvr4) did not resist to PVYV isolate 24 at greenhouse condition. CM334 originated $P v r 4$ and $p v r 2^{3}$ resistance also was not effective for PVYV both aphid transmission and under protected cultivation experiments. Şahinbey variety selected from blocky type pepper population in Gaziantep and other blocky type lines also did not resist to PVYV under both inoculation methods (Table 2).

PVYV transmitted by grafting and aphids persistent circulative manner not through seed or by mechanical inoculation (Yonaha et al., 1995) except mix infection with umbraviruses like as Potato leaf roll virus (Ryabov et al., 2001). Restriction of mechanical inoculation and absence of infectious clone of PVYV obstructs to determine response of pepper genotypes to the agent wide spreading Worldwide. The evolutionary period of the poleroviruses has been estimated as with in the last 4000 years. This evolutionary change is shorter than that proposed for the Potyviridae which is including species causing the most destructive diseases on plants (Pagán and Holmes, 2010).
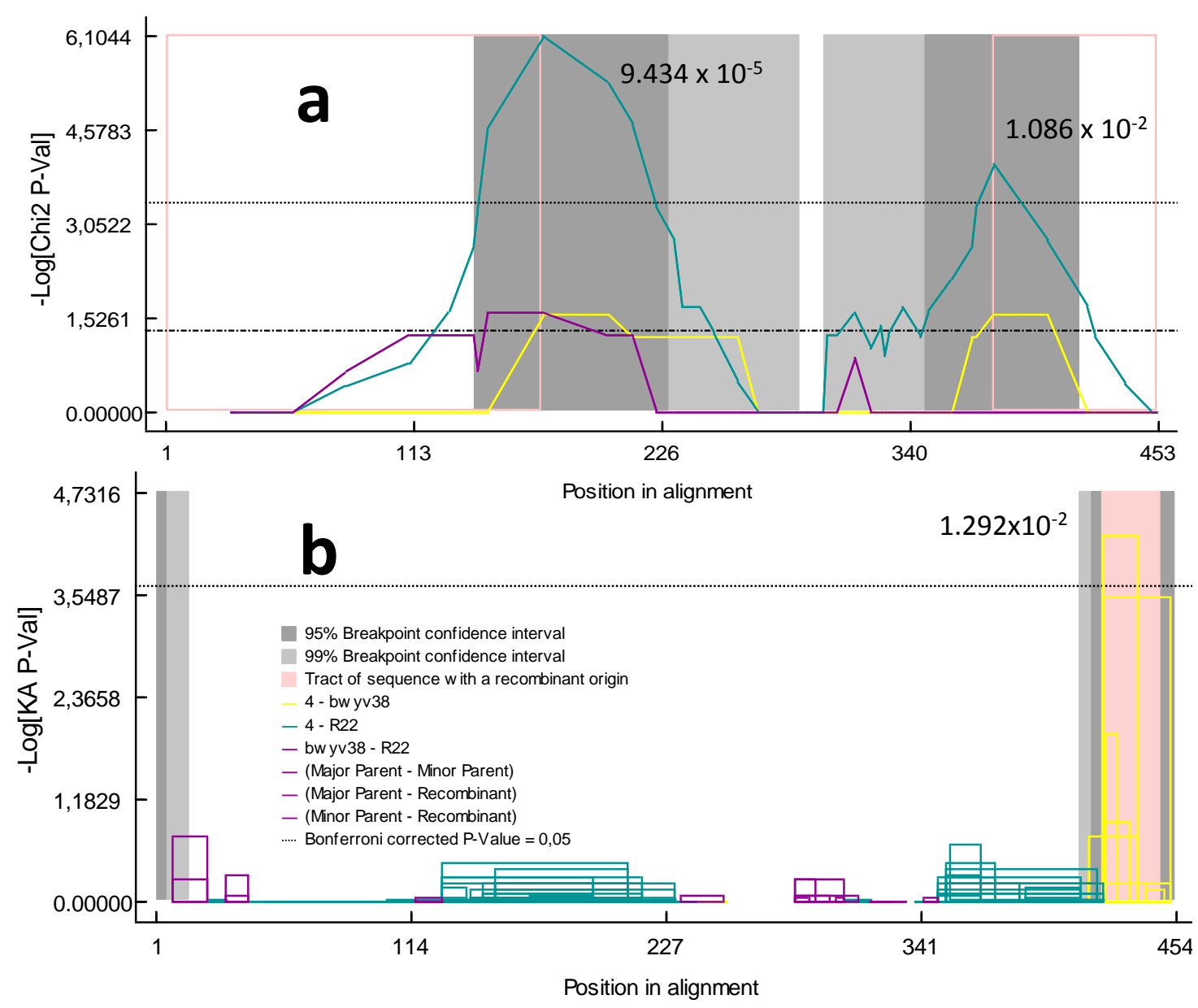

Figure 5. The main putative recombination event of major parent: PVYV isolate 15 and minor parent: PVYV isolate 21 by MaxChi (9.434 x 10-5) for PVYV isolate 24 and $3 \mathrm{Seq}$ (1.086 x 10-2) (a) and PVYV isolate 4 and BWYV isolate 38 by GENECONV (1.292 $\times 10-2)$ for PVYV isolate 


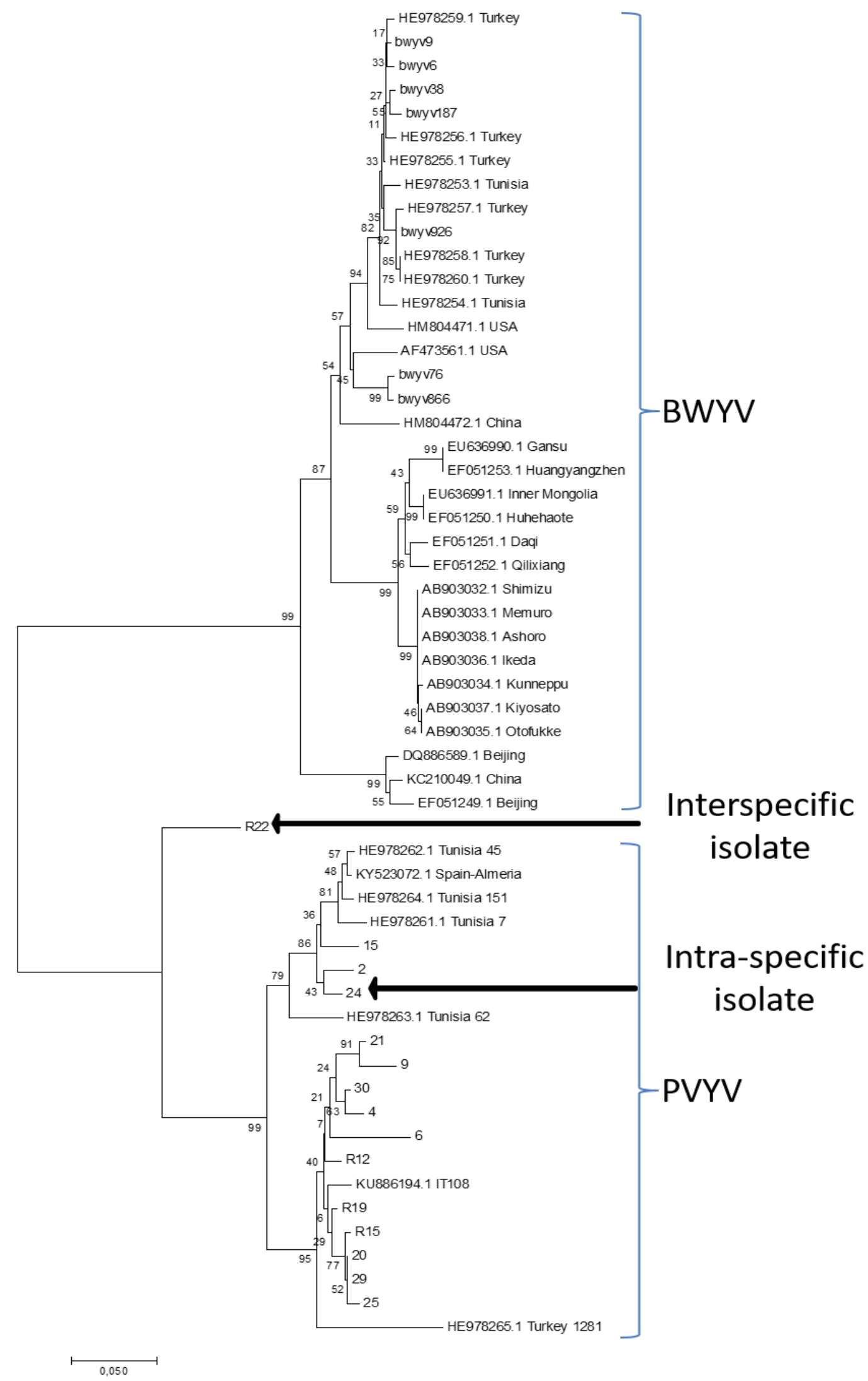

Figure 6. Phylogenetic tree of PVYV and BWYV using the neighbor-joining method clustered together in the bootstrap test (500 replicates) conducted in MEGA7 
Table 2. Response of the pepper genotypes to PVYV. (S: susceptible nt: not tested)

\begin{tabular}{c|c|c}
\hline Pepper genotype & Aphid transmission & Greenhouse conditions \\
\hline Yolo Wonder $\left(p v r 2^{+}\right)$ & $\mathrm{S}$ & $\mathrm{S}$ \\
Yolo Y $\left(p v r 2^{l}\right)$ & $\mathrm{S}$ & $\mathrm{S}$ \\
Florida VR2 $\left(p v r 2^{2}\right)$ & $\mathrm{nt}$ & $\mathrm{S}$ \\
W4 $(P v r 4)$ & $\mathrm{nt}$ & $\mathrm{S}$ \\
CM 334 $\left(P v r 4^{+} p v r 2^{3}\right)$ & $\mathrm{S}$ & $\mathrm{S}$ \\
Er Fu Tou & $\mathrm{nt}$ & $\mathrm{S}$ \\
Sahinbey & $\mathrm{S}$ & $\mathrm{S}$ \\
E01 & $\mathrm{S}$ & $\mathrm{S}$ \\
E04 & $\mathrm{S}$ & $\mathrm{S}$ \\
E07 & $\mathrm{S}$ & $\mathrm{S}$ \\
E14 & $\mathrm{S}$ & $\mathrm{S}$ \\
E17 & $\mathrm{S}$ & $\mathrm{nt}$ \\
E26 & $\mathrm{S}$ & $\mathrm{S}$ \\
E29 & $\mathrm{S}$ & $\mathrm{S}$ \\
E32 & $\mathrm{S}$ & $\mathrm{S}$ \\
E34 & $\mathrm{S}$ & $\mathrm{S}$ \\
Y08 & $\mathrm{S}$ & $\mathrm{S}$ \\
Y32 & $\mathrm{S}$ & $\mathrm{S}$ \\
\hline
\end{tabular}

Gibbs et al. (2008) indicated that the evolution of potyvirus CP region has been occurred in the last 6,560 years. The high evolution rate of the Luteoviruses and Poleroviruses can be change their host selectiveness. As a matter of fact that Pepper vein yellows virus has been detected on Physalis spp. (Fig. 1d) a weed host in this study. Adnyani (2018) detected the PVYV on cucurbit plants in Bali. Ghosh et al. (2019) reported whitefly (Bemisia tabaci)-transmitted polerovirus known as exclusively transmitted by aphids, and named the new virus as Pepper whitefly-borne vein yellows virus (PeWBVYV) highly homologous to Pepper vein yellows virus.

\section{Conclusion}

Recently described poleroviruses Pepper vein yellows virus and Beet western yellows virus has been spreading on pepper cultivation areas in Turkey and other countries in the World. The isolates of the PVYV can be easily changing their genetic structure even restricted geographical region because of its high recombination ability. PVYV can be evolved both intra and interspecific recombination. Pvr alleles are not contributing any resistance to PVYV.

Because of appearance new vectors such as insect resistance whitefly for their transmission and reported new host range of PVYV along with their relative viruses will threaten both pepper and other crops cultivated in the world in the future. The epidemiology of PVYV and biological, serological and pathological properties of isolates should be investigated in next studies. The improvement of infectious clone can be enabled to determine response of pepper genotype to PVYV. The availability of infectious clones will facilitate investigation of resistance genes whether dominant or recessive in pepper and other crops. 
Acknowledgements. This project was partly supported by Scientific Research Department of Kilis 7 Aralik University with 2013/1/MAP/04 project number. Thanks to anonymous reviewers for their constructive comments.

\section{REFERENCES}

[1] Adnyani, N. N. P. (2018): Deteksi Pepper vein yellows virus yang berasosiasi dengan penyakit yellow vein banding pada tanaman mentimun di tabanan-BALI. - Dwijenagro $8(2)$.

[2] Alfaro-Fernández, A., ElShafie, E. E., Ali, M. A., El Bashir, O. O. A., Córdoba-Sellés, M. C., Ambrosio, M. F. S. (2014): First report of pepper vein yellows virus infecting hot pepper in Sudan. - Plant Disease 98(10): 1446-1446.

[3] Ben-Chaim, A., Paran, I. (2000): Genetic analysis of quantitative traits in pepper (Capsicum annuum). - Journal of the American Society for Horticultural Science 125(1): 66-70.

[4] Buzkan, N., Arpaci, B. B., Simon, V., Fakhfakh, H., Moury, B. (2013): High prevalence of poleroviruses in field-grown pepper in Turkey and Tunisia. - Archives of Virology 158(4): 881-885.

[5] Caranta, C., Palloix, A., Lefebvre, V., Daubeze, A. M. (1997); QTLs for a component of partial resistance to cucumber mosaic virus in pepper: restriction of virus installation in host-cell. - Theor. Appl. Genet. 94: 431-438.

[6] Daubeze, A. M., Hennart, J. W., Palloix, A. (1995): Resistance to Leveillula taurica in pepper (Capsicum annuum) is oligogenically controlled and stable in Mediterranean regions. - Plant Breeding 114: 327-332.

[7] Desbiez, C., Joannon, B., Wipf-Scheibel, C., Chandeysson, C., Lecoq, H. (2011): Recombination in natural populations of watermelon mosaic virus: new agronomic threat or damp squib? - Journal of General Virology 92(8): 1939-1948.

[8] Dombrovsky, A., Glanz, E., Pearlsman, M., Lachman, O., Antignus, Y. (2010): Characterization of Pepper yellow leaf curl virus, a tentative new Polerovirus species causing a yellowing disease of pepper. - Phytoparasitica 38(5): 477-486.

[9] Fiallo-Olivé, E., Navas-Hermosilla, E., Ferro, C. G., Zerbini, F. M., Navas-Castillo, J. (2018): Evidence for a complex of emergent poleroviruses affecting pepper worldwide. Archives of Virology 163(5): 1171-1178.

[10] Florini, D. A., Zitter, T. A. (1986): Cucumber mosaic-virus (CMV) in peppers (Capsicum annиит L) in New-York, and associated yield losses. - Phytopathology 76(6): 652-652.

[11] Ghosh, S., Kanakala, S., Lebedev, G., Kontsedalov, S., Silverman, D., Alon, T., Mor, N., Sela, N., Luria, N., Dombrovsky, A., Mawassi, M., Haviv, S., Czosnek, H., Ghanima, M. (2019): Transmission of a new polerovirus infecting pepper by the whitefly Bemisia tabaci. - Journal of Virology JVI-00488. DOI: 10.1128/JVI.00488-19.

[12] Gibbs, A. J., Ohshima, K., Phillips, M. J., Gibbs, M. J. (2008): The prehistory of potyviruses: their initial radiation was during the dawn of agriculture. - PLoS One 3(6): e2523.

[13] Green, S. K., Kim, J. S. (1991): Characteristics and Control of Viruses Infecting Peppers: A Literature Review. - In: Technical Bulletin 18. Asian Vegetable Research and Development Center, Taipei.

[14] Janzac, B., Fabre, M. F., Palloix, A., Moury, B. (2009): Phenotype and spectrum of action of the Pvr4 resistance in pepper against potyviruses, and selection for virulent variants. Plant Pathology 58(3): 443-449.

[15] Kamran, A., Lotos, L., Amer, M. A., Al-Saleh, M. A., Alshahwan, I. M., Shakeel, M. T., Ahmad, M. H., Umar, M., Katis, N. I. (2018): Characterization of pepper leafroll chlorosis virus, a new polerovirus causing yellowing disease of bell pepper in Saudi Arabia. - Plant Disease 102(2): 318-326. 
[16] Kenyon, L., Kumar, S., Tsai, W. S., Hughes, J. D. A. (2014): Virus Diseases of Peppers (Capsicum spp.) and Their Control. - In Series: Advances in Virus Research (Vol. 90). Academic Press, Amsterdam, pp. 297-354.

[17] Knierim, D., Deng, T. C., Tsai, W. S., Green, S. K., Kenyon, L. (2010): Molecular identification of three distinct Polerovirus species and a recombinant Cucurbit aphid-borne yellows virus strain infecting cucurbit crops in Taiwan. - Plant Pathology 59(5): 991-1002.

[18] Knierim, D., Tsai, W. S., Kenyon, L. (2013): Analysis of sequences from field samples reveals the presence of the recently described pepper vein yellows virus (genus Polerovirus) in six additional countries. - Archives of Virology 158(6): 1337-1341.

[19] Kumar, S., Stecher, G., Tamura, K. (2016): MEGA7: Molecular Evolutionary Genetics Analysis version 7.0 for bigger datasets. - Molecular Biology and Evolution 33: 18701874.

[20] Lapidot, M., Paran, I., Ben-Joseph, R., Ben-Harush, S., Pilowsky, M., Cohen, S., Shifriss, C. (1997): Tolerance to cucumber mosaic virus in pepper: development of advanced breeding lines and evaluation of virus level. - Plant Dis. 81: 185-188.

[21] Lefebvre, V., Palloix, A., Caranta, C., Pochard, E. (1995): Construction of an intraspecific integrated linkage map of pepper using molecular markers and doubled-haploid progenies. - Genome 38: 112-121.

[22] Lole, K. S., Bollinger, R. C., Paranjape, R. S., Gadkari, D., Kulkarni, S. S., Novak, N. G., Sheppard, H. W., Ray, S. C. (1999): Full-length human immunodeficiency virus type 1 genomes from subtype C-infected seroconverters in India, with evidence of intersubtype recombination. - Journal of Virology 73(1): 152-160.

[23] Lotos, L., Olmos, A., Orfanidou, C., Efthimiou, K., Avgelis, A., Katis, N. I., Maliogka, V. I. (2017): Insights into the etiology of polerovirus-induced pepper yellows disease. Phytopathology 107(12): 1567-1576.

[24] Maina, S., Edwards, O. R., Jones, R. A. (2016): First complete genome sequence of Pepper vein yellows virus from Australia. - Genome Announc. 4(3): e00450-16.

[25] Martin, D. P., Murrell, B., Golden, M., Khoosal, A., Muhire, B. (2015): RDP4: detection and analysis of recombination patterns in virus genomes. - Virus Evolution 1(1). https://doi.org/10.1093/ve/vev003.

[26] Moury, B., Verdin, E. (2012): Viruses of Pepper Crops in the Mediterranean Basin: A Remarkable Stasis. - In Series: Advances in Virus Research (Vol. 84). Academic Press, Amsterdam, pp. 127-162.

[27] Murakami, R., Nakashima, N., Hinomoto, N., Kawano, S., Toyosato, T. (2011): The genome sequence of pepper vein yellows virus (family Luteoviridae, genus Polerovirus). - Archives of Virology 156(5): 921-923.

[28] Pagán, I., Holmes, E. C. (2010): Long-term evolution of the Luteoviridae: time scale and mode of virus speciation. - Journal of Virology 84(12): 6177-6187.

[29] Paran, I., Aftergoot, E., Shifriss, C. (1998): Variation in Capsicum annuum revealed by RAPD and AFLP markers. - Euphytica 99: 167-173.

[30] Parrella, G., Ruffel, S., Moretti, A., Morel, C., Palloix, A., Caranta, C. (2002): Recessive resistance genes against potyviruses are localized in colinear genomic regions of the tomato (Lycopersicon spp.) and pepper (Capsicum spp.) genomes. - Theoretical and Applied Genetics 105(6-7): 855-861.

[31] Ryabov, E. V., Fraser, G., Mayo, M. A., Barker, H., Taliansky, M. (2001): Umbravirus gene expression helps Potato leafroll virus to invade mesophyll tissues and to be transmitted mechanically between plants. - Virology 286(2): 363-372.

[32] Sacchi, H., Melo, A. M. T., Colariccio, A. (2003): Reação de progênies de pimentão ao Potato Virus Y. - Bragantia 62(1): 53-60.

[33] Saitou, N., Nei, M. (1987): The neighbor-joining method: a new method for reconstructing phylogenetic trees. - Molecular Biology and Evolution 4: 406-425. 
[34] Tan, W. P., Dong, Y. Z., Sun, X. H., Liang, Y. C., Liu, H. X., Zhu, X. P. (2015): The first identification of Pepper vein yellows virus in Shandong Province, China. - Plant Disease 99(9): 1288.

[35] Thompson, J. D., Gibson, T. J., Higgins, D. G. (2003): Multiple sequence alignment using ClustalW and ClustalX. - Current Protocols in Bioinformatics 1: 2-3.

[36] Villanueva, F., Castillo, P., Font, M. I., Alfaro-Fernández, A., Moriones, E., NavasCastillo, J. (2013): First report of Pepper vein yellows virus infecting sweet pepper in Spain. - Plant Disease 97(9): 1261-1261.

[37] Yonaha, T., Toyosato, T., Kawano, S., Osaki, T. (1995): Pepper vein yellows virus, a novel luteovirus from bell pepper plants in Japan. - Japanese Journal of Phytopathology 61(3): 178-184. 